\title{
VIRGÍLIO VÁRZEA: AFRICANOS, AFRODESCENDENTES E NAVIOS NEGREIROS
}

\section{VIRGÍLIO VÁRZEA: AFRICANS, AFRO-DESCENDANTS AND SLAVE SHIPS}

\author{
Gustavo Krieger Vazquez' \\ [https://orcid.org/0000-0001-6579-1454] \\ DOI: 10.30612/raido.v15i37.14315
}

\begin{abstract}
RESUMO: Em obras do autor catarinense Virgílio Várzea (nascido em 1863 em Desterro, atual Florianópolis), há perspectivas que refletem parte da multiplicidade de ideias raciais presentes na sociedade da época, recém-saída da escravidâo e buscando se consolidar como República. Em contos e no estudo Santa Catarina - a Ilha, há visōes diversas, desde uma negaçăo da presença negra na capital de Santa Catarina e uma exaltaçăo à raça branca, até personagens afrodescendentes significativas. Analisaremos também dois contos seus que lidam com navios negreiros: um que dignifica a atividade do tráfico, e outro, versâo de um poema de Heinrich Heine, que faz uso de um humor ácido para mostrar a crueldade de seus praticantes. Essas ideias, à primeira vista díspares, săo reflexo de um autor versátil e questionador que se encontrava em uma sociedade ideologicamente transtornada.
\end{abstract}

Palavras-chave: Virgílio Várzea; racismo; regionalismo; Florianópolis; Belle Époque.

ABSTRACT: In works of Virgílio Várzea (born in 1863 in Desterro, now Florianópolis, state of Santa Catarina), there are perspectives that reflect part of the multiplicity of racial ideas present in the society of the time, recently out of slavery and seeking to consolidate itself as a Republic. In short tales and in the study Santa Catarina - the Island, there are different visions, ranging from a denial of the presence of people of color in the capital of Santa Catarina and an exaltation of the white race, to significant Afro-descendant characters. We will also analyze two tales of Várzea that deal with slave ships: one that dignifies the slave trade, and another, a version of a poem by Heinrich Heine, which uses an acid humor to show the cruelty of its practitioners. These ideas, at first glance incongruous, are a reflection of a versatile and questioning author who found himself in an ideologically disturbed society.

Keywords: Virgílio Várzea; racism; regionalism; Florianópolis; Belle Époque.

\section{SANTA CATARINA - A ILHA E O BRANQUEAMENTO}

A obra Santa Catarina - a Ilha, lançada por Virgílio Várzea em 1900, mantém-se como referência, até hoje, em estudos históricos, antropológicos e geográficos da ilha

1 Universidade Federal do Paraná, Curitiba. Graduado em Filosofia. Mestre e doutorando em Literatura pela UFPR.E-mail: kriegervazquez@hotmail.com. 
de Florianópolis. No livro, a presença de homens e mulheres negros é pequena, e a justificativa para isso é dada pelo autor no seguinte trecho:

Na populaçăo catarinense (a năo ser nas colônias, com o alemăo ou o italiano) năo há quase cruzamento, sendo raro encontrar, entre ela, o tipo indígena do norte do Brasil ou o traço fisiológico do negro, que ali năo prevaleceu senăo insignificantemente, em pequeno número de mestiços, porque o tráfico do africano nessas plagas apareceu tardiamente, logo reprimido pelas nossas leis, e mais pelos ingleses [...] (VÁRZEA, 1985, p. 22).

O primeiro ponto a ser considerado é a questâo de uma suposta "insignificância" da presença de africanos e afrodescendentes em Desterro/Florianópolis. Na realidade, a populaçăo negra estava longe de ser pouca. Se nos censos realizados de 1864, 1866 e 1872 , a porcentagem de habitantes negros permaneceu constante, próxima de $25 \%$ da populaçăo, mesmo imediatamente após a Aboliçăo, o número de habitantes negros manteve-se considerável: em 1890 ele era 18,26\% (CARDOSO \& IANNI, 1960, p. 93). Săo valores significativos, e que indicam uma tendência no texto de Várzea.

Isso ficará mais claro se buscarmos entender a visâo racial global do autor. Em $A$ Ilha, há dois momentos em que a raça branca é diretamente mencionada. Uma delas é continuaçáo do trecho citado anteriormente:

[...] o povo catarinense é essencialmente ariano, com particularidade nos centros alemáes ou italianos, como Joinville, Blumenau, Brusque, Nova Trento, Orleans e Nova Veneza, cidades e vilas que foram outrora colônias, e cujas populaçóes hăo de ser, no futuro, o fator de um novo tipo brasileiro interessante, superior e perfeito... (VÁRZEA, 1985, p. 22).

Adiante no texto, ao discutir sobre o carro de boi, que teria sido inventado por alguma raça branca, o escritor afirma que "só a raça ariana - a raça superior entre todas - pôde levar a cabo, em um dado período do seu adiantamento, a confecçāo do veículo" (VÁRZEA, 1985, p. 199).

É evidente que há uma forte ideologia estruturando tais palavras. Assim, a origem e os objetivos dessa obra precisam ser considerados. Feita com apoio do governo do estado de Santa Catarina, A Ilha soa como uma espécie de propaganda. Florianópolis é comparada a cidades europeias, sua beleza encanta os turistas, famosos estudiosos por lá passaram e se admiraram, há a descriçấo de várias indústrias e cultivos locais que, dado maior apoio financeiro, haveriam de crescer etc. Há, inclusive, louvor à República:

[...] vindo o regime definitivo da República, transformador das coisas passadas, mudar a antiga província em Estado Federativo - Santa Catarina adquiriu outro aspecto, outra fisionomia, desenvolvendo-se e progredindo mais, neste último decênio, que durante os sessenta e sete anos experimentados como província do Império. (VÁRZEA, 1985, p. 15).

A República simbolizava, na época, o fim de uma Monarquia escravista. Porém, năo se buscava, em Santa Catarina, uma inserção de africanos e afrodescendentes na sociedade; ao contrário, a intençâo era substituir o escravo pelo imigrante branco:

[...] o movimento abolicionista em Santa Catarina foi um "assunto de branco", e que tentou excluir o negro do centro desse debate. [...] 
O discurso abolicionista dos jornais catarinenses foi eminentemente imigrantista, pois, ao defender a libertaçáo do escravo, năo levou em conta a problemática do negro livre, segregando-o e condenando-o a permanecer à margem do processo civilizatório em que estavam empenhadas as elites.

A crítica à escravidăo estava, portanto, imbuída de uma base racista, e no momento em que o imigracionismo aparece como parte de um projeto de modernizaçăo, em que o branqueamento da naçăo era condiçăo essencial. Assim, o negro, pelas implicaçóes decorrentes da escravidăo, ficaria marginalizado desse projeto civilizatório [...] (PEDRO et al, 1988, p. 60).

Lilia Schwarcz (2012, p. 11), falando da história do Brasil em geral, resume que "a cor branca, poucas vezes explicitada, é sempre uma alusăo, quase uma bênçăo; um símbolo dos mais operantes e significativos, até os dias de hoje". Em Santa Catarina do fim do século XIX e início do século XX, isso estava em evidência. Tanto o público visado com a obra Santa Catarina - A Ilha, quanto as pessoas que a financiaram, comungavam, parcial ou totalmente, com as ideias lá expostas, que refletiam, por sua vez, esse desejo por uma sociedade plenamente branca. Mais que isso, assim como a bela natureza e a promissora indústria, a suposta inexistência de negros também fazia parte da propaganda. Era uma via de dois lados: quanto menos negros, melhor; quanto mais brancos, melhor.

Luiz Alberto de Souza, em seu artigo "Homens bons para o amanhă: o pensamento racial e perspectivas republicanas em A Ilha, de Virgílio Várzea", explica como a obra do autor catarinense foi ferramenta em defesa e propagaçăo de uma ideologia reinante, que associava as raças presentes em uma naçấo com as capacidades de progresso dessa:

Assim, mais do que a expressăo de um ponto de vista individual e íntimo do autor, a construçáo dessa realidade antropológica corresponde à satisfaçáo de uma expectativa política própria àqueles grupos no poder em 1900. A defesa da arianidade catarinense em $A$ Ilha significa também a defesa, ante os representantes da República, do valor e da viabilidade de Santa Catarina dentro do grande esforço de construçăo de um país moderno, civilizado e progressista. (SOUZA, 2007, p. 15).

O branqueamento - a superioridade da raça branca, a raça negra sendo desprezada - era parte essencial da ideologia presente em Santa Catarina no início do século XX. Como todo princípio determinista e com intençôes propagadoras, nâo foi algo que se restringiu a livros, mas que agiu na prática:

A Florianópolis do início do século XX foi, assim como outras capitais brasileiras, palco de políticas públicas que resultaram na espacializaçâo da pobreza na cidade. Em nome da higienizaçăo, do saneamento e da modernizaçăo, reformas urbanas afastaram as camadas populares de áreas que historicamente ocupavam [...]. Esse processo estabeleceu inúmeras barreiras que dificultavam a ascensăo social das populaçóes pobres, predominantemente de origem africana, impedindo também que gozassem de direitos fundamentais como educaçăo, moradia digna, saneamento urbano, transporte público, assistência médica, etc. [...] todos os investimentos em infraestrutura eram canalizados para os bairros onde residia a populaçăo mais abastada. (MARIA, 2013, p. 264-265). 
Através da força proveniente da autoridade, foi possível a exclusâo racial. Devemos notar que essa normalizaçăo da segregaçăo, o que gera a naturalizaçấo da discriminaçăo, năo surgiu com a República, embora tenha encontrado nela solo bastante fértil. Em Desterro, leis que cerceavam os africanos e afrodescendentes estavam em aplicaçăo há muito:

Por uma Postura (lei) Municipal de 1831 o escravo era proibido de cantar nas ruas, salvo quando era para facilitar o trabalho. Em 1833, tornou-se proibido alugar casa sem autorizaçăo, por escrito, do proprietário. Em 1845 foi vedada a compra de drogas e medicamentos, a năo ser canela, cravo, cominho, erva-doce e pimenta. Em 1856 o subdelegado de polícia proíbe, por meio de aviso oficial, qualquer "ajuntamento de escravos nos armazéns e tabernas [...]". Aliás, já desde 1831 estavam proibidas as danças e batuques [...] (PEDRO et al, 1988, p. 42).

Embora tenha sido uma parte do todo ideológico que buscou negar a importância do africano e afrodescendente na sociedade florianopolitana, ao mesmo tempo em que exaltava a raça branca, A Ilha năo deve servir como parâmetro definitivo dos pensamentos de Virgílio Várzea. Suas ideias em relaçăo aos africanos e afrodescendentes eram mais complexas do que a de um simples defensor da raça ariana e da limpeza étnica, e veremos isso a partir de sua ficçăo, menos estudada do que seu livro sobre a ilha de Florianópolis.

\section{OS AFRODESCENDENTES NA FICÇÃO DE VIRGÍLIO VÁRZEA}

Em grande parte dos contos de Várzea, temos Desterro/Florianópolis durante o que veio a ser conhecido como sendo a Belle Époque brasileira. Em relaçâo ao locus, esses contos tendem a se desenvolver em dois ambientes: o rural ou o marítimo. Sobre este, José Veríssimo, em um estudo de 1904, criticava:

O Sr. Várzea conhece e ama e sente as coisas navais e marítimas; nos seus contos há belas e comovidas manifestaçôes deste aspecto do seu sentimento poético: marinhas, cenas de navegaçăo ou da existência marítima, paisagens da sua terra natal, terra de lindos aspectos marítimos e de vida marítima. Nâo serei eu quem o aconselhe a abandonar estes assuntos, que năo só conhece, mas que, segundo a palavra em moda, adora. Alguma variedade mais me atreverei a aconselhar [...] (VERÍSSIMO, 1904, p. 293).

A variedade é fornecida pelos contos rurais, nos quais Várzea busca caracterizar a colonizaçăo de certos recantos da ilha por lavradores. O conflito homem x natureza é ponto central das narrativas, com os eventos naturais causando mortes e deslocamentos; há também a bebida como flagelo de alguns moradores, mulheres viúvas ou abandonadas que precisam manter suas famílias, e a retrataçăo da cultura local, com festas e os princípios religiosos que guiam a vida dos homens e mulheres rurais. Alguns poucos contos regionalistas mostram a cidade grande como um local que atrai o pobre sertanejo, como "Separaçăo" e "Romance de um rapaz", ambos de Mares e campos (1895). Săo temas que refletem as mudanças ocorrendo na época:

[...] o final do século XIX traz uma queda ainda maior das atividades agrícolas [...] a populaçăo urbana de Desterro cresce e ocupa áreas que antes eram da agricultura. 
Nossa Senhora do Desterro, capital da Província, adquire ares, se năo mais cosmopolitas, ao menos mais urbanos e de centro administrativo, que compra produtos agrícolas de fora, deixando para as freguesias do interior da Ilha uma face mais rural e de subsistência. (CESCO, 2011, p.12).

Essa populaçâo rural simples, de pequenas freguesias, é a que está presente na obra ficcional regionalista de Várzea; tanto nela quanto nos contos marítimos, há a presença da populaçâo africana e afrodescendente, que fornece desde participaçôes breves até um protagonismo significativo.

Primeiramente, isolamos de Mares e campos e Histórias rústicas (1904) momentos em que negros săo figurantes nas histórias, sendo mencionados brevemente e apenas raramente por nome. No conto "Na ilhota", durante uma festa, "homens descalços, rapazes e mulheres das proximidades, com crioulos forros que vadiavam, grupavam-se à porta da rua, arregalando os olhos curiosos" (VÁRZEA, 2003, p. 47); mais adiante, somos informados que "o tocador de gaita, um mulato anguloso, chupado, com uma pera satânica de Mefistófeles, um lenço de chita ao pescoço, rouquejava uma quadrilha" (p. 49). Em "A vela dos náufragos", após um desastre marítimo, "até na cozinha as velhas pretas da casa faziam um coro vivo de pranto" (p. 67). Em "No meu sítio natal", somos informados que, em uma praça, há "as pretas doceiras do adro" (1904, p. 113). Em "Um enterro no sítio", enquanto um grupo deixa a igreja, "mais atrás caminha um preto, idoso e curvo talvez pelos seus sessenta anos de enxada, que leva a tampinha do caixăo" (p. 139-140). Em "A morte do domador", durante um evento, para ajudar outra personagem, "o Inácio, o velho preto carreiro do Manoel Luís, correu imediatamente à casinha dos arreios..." (p. 193).

Outras mençóes se passam durante ou se referem à época da escravidăo: "Os escravos já dormem" (VÁRZEA, 1904, p. 128), diz um dos dois protagonistas do conto "À luz das estrelas"; adiante, o narrador diz que "e assim chegaram a um rancho, onde os esperava uma grande canoa de voga tripulada por negros" (p. 130). Em "Velha paixăo", temos um momento em que "...um dos escravos do Vidal se precipitou pela porteira com uma peça de rijo cabo de cairo à cabeça" (p. 160). Em "Miss Sarah", na descriçăo da habitaçăo de um senhor de escravos, somos informados sobre "a antiga cozinha patriarcal, em que, à noite, se reunia a negrada doméstica - crioulas robustas e entroncadas, de grandes mamas túmidas, alimentando as crias". Na oraçăo seguinte, é mencionada a "senzala, onde se recolhiam, outrora, depois da faina das redes e das roças, como uma manada de gado, os hércules de ébano da lavoura" (2003, p. 115).

Salta aos olhos as comparaçôes entre africanos e afrodescendentes e animais. No conto "O chimpanzé marujo", ocorre uma comparaçăo ao reverso: um capitâo apresenta a Victor...

[...] um estranho negro, de baixa estatura mas atlético, horrivelmente peludo, cujo enorme prognatismo, a boca rasgada e grossa, onde os caninos se mostravam colossais e ameaçadores, lhe davam um aspecto feroz. Vestido de zuarte, e com uma faixa escarlate à cintura, o homem apoiado a uma vara de pinho segura à máo esquerda e coxeando um pouco nas suas pernas em X [...] (VÁRZEA, 1904, p. 38-39, grifo do autor).

Logo adiante, somos informados de que o suposto "homem" é um chimpanzé. 
Há outros casos assim, o que veremos nas próximas seçōes. Fato é que, na estética, os prejuízos lançados contra homens e mulheres negros faziam contraponto às consideraçôes positivas em relaçăo a homens e mulheres brancos. Se a raça negra era vista como "feia", se era comparada com animais, dentro da suposta "superior" raça branca temos, em A Ilha, por exemplo, uma exaltaçăo à beleza das mulheres rurais catarinenses - isto é, imigrantes portuguesas e suas descendentes:

[...] porquanto verdadeiras belezas, em nossa opiniāo, quer na corpulência, quer na harmonia doce e seráfica dos traços fisionômicos, se encontram com maior frequência, e em toda a plenitude de encantos, nas freguesias e arraiais interiores, pelas roças, pelos sítios.

E isto se explica naturalmente, pela saúde e liberdade do campo, onde o clima é sempre doce, o ar sempre puro e desenervante, e onde a vida corre despreocupada e feliz, quase sem impressōes desagradáveis ou opressóes morais, que tanto afetam a existência nos meios populosos, em que há grande concorrência e é mais dolorosa a luta pela vida; e explica-se ainda pela conservaçăo integral do primitivo tipo açoriano que aí ficou vitorioso, tipo que, segundo viajantes e escritores, é dos mais belos da raça portuguesa [...] (VÁRZEA, 1985, p. 29).

Lendo esse trecho, podemos levantar a hipótese de que Várzea, ao criticar o africano e o afrodescendente do ponto de vista estético, tenha representado, mesmo que inconscientemente, o quanto essas pessoas sofriam, as injustiças e infelicidades com as quais conviviam. Se a falta quase total de "opressôes morais" e da "dolorosa luta pela vida" gera a beleza, pode-se deduzir que, onde esses fatores negativos existem de forma categórica, a "feiúra" será encontrada.

\subsection{ANÁLISE DE “O DIA DE S. JOÃO” E “O VELHO PROFESSOR”}

Tendo visto casos em que africanos e afrodescendentes aparecem de forma breve e esparsa, lancemos uma luz mais forte em dois contos em que a presença deles é mais do que significativa, é determinante.

Em "O dia de S. Joâo", de Histórias rústicas, o narrador rememora como eram os dias de tal festividade durante sua infância. Ocupando grande parte do conto está Clemência, uma agregada descrita como sendo "parda" e, mais adiante, "mestiça" (VÁRZEA, 1904, p. 89-90), que vive com a família do narrador.

Os primeiros dados que recebemos dessa personagem săo negativos: ela é comparada a um animal, algo que se encontra ocasionalmente na obra de Várzea, como vimos. Clemência é "muito feia e desairosa, se por acaso fosse negra, tivesse a fronte deprimida e o competente prognatismo, dir-se-ia uma chimpanzé [...] uma descendente direta dos antropoides". Porém, Várzea nâo equipara as feiçôes com o caráter ou desenvolvimento intelectual. Clemência recebe uma grande quantidade de elogios, mais de duas páginas, das quais selecionamos alguns: seja em relaçấo a seu físico ("extraordinariamente robusta, de uma saúde resistente, poderosa, formidável"); sua bondade e simpatia ("uma individualidade de uma índole naturalmente doce, plácida, superior. Temperamento expansivo e alegre, trazia um constante e sincero riso na boca, riso feliz de cordialidade e de amor para todos"); mais adiante seu afeto é alargado para toda a sua raça ("imperava nela, acima de tudo, essa afetividade levada ao último 
extremo e quase mórbida, que caracteriza a raça negra."); sua ética ("de um moral adamantino: a sua alma jamais conhecera a maldade, a traiçăo, a perfídia, pois que era só afeto, dedicaçấo e carinho"); sua capacidade de perdâo ("Sabia relevar e esquecer, com incomparável generosidade, todas as ofensas que lhe faziam"); sua inteligência e talento para o trabalho ("Inteligente, sensata e muito arguta, embora analfabeta, era de uma atividade prodigiosa e năo havia trabalho, nem investidura, nem incumbência doméstica, e mesmo de qualquer outro gênero, que ela náo desempenhasse de modo completo, irrepreensível, cabal") (VÁRZEA, 1904, p. 89-91). ${ }^{2}$

Os elogios sâo amorosos - o narrador lembra com afeto dessa mulher. Sua história é sucintamente explicada: tendo sido escravizada, entende-se que ela fugiu do cativeiro e encontrou um novo lar (VÁRZEA, 1904, p. 92). Sua posiçăo na constituiçăo familiar é interessante: ela ocupa a posiçăo paterna na família.

Tornou-se entăo, desde logo, um excelente auxiliar de minha măe e como um desdobramento, ou uma segunda pessoa dela nas lides da casa. Quando se fazia necessário um homem para decidir algum negócio de monta fora do nosso lar, era a Clemência quem ia, porque eu, o mais velho dos filhos, năo tinha ainda dez anos, e meu pai vivia sempre no mar, no comando dos grandes paquetes da Linha do Sul, passando somente, de mês a mês, um ou dois dias com a família. (VÁRZEA, 1904, p. 92).

Reforçando isso, temos que Clemência tinha "um singular pendor para vestir-se à masculina", "uma Louise Michel mulata", referindo-se à comunista francesa que se vestia com trajes masculinos. Mais que isso, "podia bater-se com quaisquer homens: e eu a vi, algumas vezes, quando por eles vaiada pela estranheza do seu todo de virago, afrontá-los frente a frente e fazê-los recuar, num legitimo e possante movimento de justiça e revanche" (VÁRZEA, 1904, p. 89-90, 95-96, grifos do autor).3 É curiosa a sequência "justiça e revanche" - seria nâo apenas pelas desfeitas imediatas, mas por ter sido uma mulher escravizada?

Apesar de sua "organizaçăo externa aparentementeviril", para o narrador, Clemência:

[...] era contudo, no íntimo, profundamente feminina: o seu pranto soltava-se, sentidíssimo, à menor repreensáo e o seu peito alcanceava-se de funda amargura quando alguma criança que ela amava, algum "filho de criaçăo", acaso a tratava com indiferença e desdém, ou parecia lançá-la em abandono. (VÁRZEA, 1904, p. 90-91).

Clemência é complexa demais para o narrador, que busca compreendê-la com suas memórias infantis. A contradiçăo entre essa mulher negra que luta, que ocupa a posiçăo paterna em uma casa de brancos, e a ideia de que ela "era só afeto, dedicaçầo e carinho", indica as dificuldades do narrador em relaçăo a uma tentativa de compreensăo da mulher de quem gostava e admirava - e, também, uma indefiniçăo precisa dos arranjos familiares que estavam ocorrendo (que, pelas descriçóes do narrador, nâo

2 Essa curiosa mistura desenvolvida por Várzea entre depreciaçăo estética e valorizaçāo física, moral e intelectual em relaçăo a afrodescendentes é bastante singular; para interessados em conhecer as teorias mais usuais, recomendamos a obra $O$ espetáculo das raças, de Lilia Schwarcz.

3 A mulher com características masculinas - a "mulher-macho" - foi explorada em grandes obras do regionalismo da Belle Époque, como Dona Guidinha do Poço, de Manuel de Oliveira Paiva, Luzia-homem, de Domingos Olímpio e o conto "Ana Cabriuvana", de Valdomiro Silveira, entre outros. 
o incomodavam, ao contrário). Apesar do conto iniciar e terminar com "'que feliz e festivo foi outrora, no doce lar de meus pais, o dia de S. Joâo!" (VÁRZEA, 1904, p. 87 e 99), sabemos que o lar, embora pudesse ser possuído pelo seu pai e pela sua măe, era, mais que dependente de, até mesmo organizado por Clemência. Nisso está a importância do recorte de memórias que é apresentado desse dia importante e alegre: pai ausente, mâe mal mencionada, enquanto o narrador lembra-se carinhosamente dessa mulher que "ora estava a meu lado, ora em voltas domésticas no interior do nosso lar" (VÁRZEA, 1904, p. 97).

Em determinado momento do conto temos outra personagem "parda", Theodoro, "criado da casa do velho Maneio e nessa época servente da loja, mas que depois estranhamente a deixou para se fazer sacristăo" (VÁRZEA, 1904, p. 94). Embora estranho para o narrador, a mudança de profissăo năo o é para o autor, que colocou as duas personagens negras presentes no conto em profissôes que lhe seriam cabíveis em Desterro/ Florianópolis da época - Clemência como agregada, Theodoro como sacristăo. Mas corroboremos isso com informaçōes de outro conto de Histórias rústicas.

Em "O velho professor", conto ambientado no Rio de Janeiro, temos Antonio Joaquim Vieira, homem que organiza um cortejo para saudar e presentear o velho professor José Theodoro Burlamaqui. O encontro do professor com seus antigos alunos é sentimental, com saudosas lembranças do passado - e com Antonio entregando ao mestre um "rico relógio de ouro cravejado de brilhantes" (VÁRZEA, 1904, p. 184), comprado por ele e por outros da comitiva.

Antonio é um afrodescendente: possui "pele brônzeo negra de núbio". Embora só tenha estudado até a escola primária de entâo, ele é "inteligente e loquaz". Além disso, ele é "tenente-coronel do corpo de polícia da Capital Federal" (p. 179). Notamos que o conto se passa no Rio de Janeiro, e isso é importante: é local onde năo seria estranho um afrodescendente alcançar o posto que alcançou na força policial, possuir dinheiro para bancar parte do custo de um relógio de ouro, além de ter uma evidente rede ampla de relaçôes sociais capaz de unir um cortejo formado por "velhos, moços e meninos" (p. 178). Havia uma "larga participaçăo do elemento nacional na economia urbana carioca" da época, situaçăo distinta do interior do estado, ou mesmo de Sáo Paulo e sua capital, onde o elemento nacional - negros, índios, caboclos etc. - "foi incorporado de maneira acessória e residual" (KOWARICK, 2019, p. 120), havendo uma grande preferência por estrangeiros.

Embora com suas próprias características, a ilha de Florianópolis, como vimos, tampouco teve uma justa participaçăo de homens e mulheres negros no mercado de trabalho. Lá, no início do século XX, uma mulher negra como agregada da casa (Clemência), ou um homem negro como sacristăo (Theodoro), é algo possível. Tirando casos assim, podemos dizer que Florianópolis nâo estava de braços abertos a homens e mulheres negros livres. Henrique Espada Lima posiciona bem a situaçăo:

O trabalho duro, um mercado de empregos restrito, oportunidades escassas e as barreiras do preconceito e do racismo marcaram muito a experiência dos libertos e afrodescendentes livres, antes e depois da Aboliçáo. As raras oportunidades de acesso a arranjos de trabalho justos, educaçâo e aprendizado de uma profissâo, propriedade e ascensăo social foram objetos de luta e de difícil conquista. (LIMA, 2013, p. 220). 
Embora seja algo relevado em seu estudo A Ilha, que, como havíamos indicado, foi financiado pelo estado de Santa Catarina e possui um viés propagandista, Várzea mostra, na ficçâo, as possibilidades de trabalho para afrodescendentes, inclusive com as diferenças entre cidades distintas - săo três homens e mulheres negros que estăo em posiçôes sociais condizentes ao meio em que se encontram.

\section{NAVIOS NEGREIROS}

Se em A Ilha temos uma visâo racista proeminente, e em certos contos retrataçôes adequadas e até mesmo positivas de africanos e afrodescendentes, os contos de Várzea que lidam com navios negreiros deixam a questáo mais complexa.

O conto "O velho Sumares", de Mares e campos, trata da vida de Sumares, homem de setenta e seis anos e descendente de uma família de marinheiros. Sua riqueza provém do tráfico negreiro; tornando-se capităo do navio Galgo, chegou a fazer trinta e seis viagens até a África para buscar escravos. Assim como Várzea viria a exaltar, em A Ilha, a beleza das mulheres brancas rurais catarinenses, a descriçăo física que o narrador de "O velho Sumares" faz do protagonista corresponde a um ideal de beleza que seria próprio da raça branca:

O Sumares [...] da máe, recebera a beleza cinzelada do busto e os grandes olhos nanquinados, imprimindo uma radiaçáo e um encanto à larga fisionomia ariana, emoldurada em bela barba basta e numa espessa cabeleira ondeada. Aos quinze anos, todo imberbe, era lindo, forte, escultural, lembrando o filho de um pescador do Pireu, ou um antigo grumete dos Argonautas. (VÁRZEA, 2003, p. 77-78).

O Galgo, em sua última viagem, retornando para casa após "tomada a última barcada de negros" (VÁRZEA, 2003, p. 76), é perseguido pelo navio inglês Conquest. O coraçâo do conto é a descriçấo vívida e detalhada do último dia de combate; mesmo bastante danificado, o barco consegue escapar com sua "carga".

A participaçâo dos homens escravizados no conto é quase nula - eles săo apenas algo adquirido e que será vendido. $O$ único momento em que săo mencionados, além de em "barcada de negros", como citado acima, é quando o Conquest atinge uma bala de canhăo na amurada do Galgo, e somos informados que "no porâo, nesse instante, correu como a zoada abafada de um gado preso, tumultuando" (VÁRZEA, 2003, p. 83) - isto é, novamente a aproximaçăo entre negros e animais.

Em "Na ilhota", também de Mares e campos, o barco Galgo, entâo renomeado Estrela, e seu capităo, Manuel Lemos, têm suas próprias aventuras; mas o passado da embarcaçấo é brevemente indicado pelo narrador:

Valente nos temporais, muito seguro, era célebre pela velocidade da marcha no tempo do tráfico dos africanos, em que, mesmo nas situaçóes mais arriscadas, soubera sempre, com êxito, em meio dos vagalhôes encapelados do Atlântico, fugir à proa perseguidora e temerosa dos cruzeiros ingleses. (VÁRZEA, 2003, p. 44-45)

Também em "Marujos", de Histórias rústicas, temos uma mençăo a Sumares, entâo capităo de outro barco, Espadarte, feita por um marinheiro entâo velho que recorda saudosamente da época do tráfico negreiro. Os ingleses săo novamente descritos como 
adversários, com o locutor afirmando que eles buscavam "recambiar a negrada": após levarem os africanos de volta a suas terras - homens e mulheres que o velho marujo chama de "carga" - deixavam os traficantes "sem recursos em qualquer praia deserta da África" (VÁRZEA, 1904, p. 48-49).

Tomando os contos em conjunto, poderia ser argumentado que, no fim das contas, está sendo feita uma retrataçăo histórica condizente com a realidade dos navios negreiros e da mentalidade de seus marujos, isto é, uma hipotética objetividade. Apesar de tal posiçấo ter a sua coerência, por mais que um autor de ficçăo se esforce para ser neutro em relaçăo às suas personagens e açôes, por mais que tente apenas descrever uma cena, o recorte feito por ele indica quais interesses receberam maior relevância em sua mente.

De um lado, o fascínio de Várzea por questōes náuticas, algo tăo evidente que chegou a ser criticado por José Veríssimo, pode tê-lo encaminhado a escrever sobre qualquer navio que conhecesse, independente das razóes morais internas. Mas mesmo que isso fosse capaz de fazê-lo ignorar os problemas da escravidâo, precisaríamos apontar que Várzea nunca escreveu um conto a partir da posiçăo do homem que é escravizado em sua terra natal e levado ao Brasil à força, ou mesmo um conto em que um homem em tal condiçăo pudesse, nem que brevemente, falar a respeito de si ou contra seus captores. Tampouco descreveu ingleses tomando um navio negreiro brasileiro e explicando as razôes da captura, a criminalidade da escravidăo etc.

Além disso, temos um conto em que a afinaçăo emocional tende a favor dos escravagistas. Em "O velho Sumares", os sentimentos que o autor desejou incitar em seus leitores, sâo o de uma aventura naval emocionante com um herói que, após certos incidentes, consegue vencer. Há uma clara intençâo, principalmente no capítulo IV, o mais longo e central à história, de que o leitor torça pelo bem-estar do Galgo e de seus tripulantes - o que inclui o desejo de que sua missâo, que é levar homens e mulheres à escravidăo, seja realizada. Importa, na trama, a tenacidade, a coragem, o talento náutico dos escravagistas envolvidos. O conto termina com:

O velho Sumares nunca mais embarcou, expirando aos noventa anos de idade, entre os carinhos deliciosos das filhas e dos netos, na sua pitoresca habitaçăo da Arataca. E a história da sua vida rude e aventurosa ainda é hoje relembrada, com inefável ternura, na placidez venturosa dos seróes, nos lares. (VÁRZEA, 2003, p. 85).

Em suma, temos uma personagem que fez trinta e seis viagens para buscar homens e mulheres na costa da África para serem vendidos como escravos, terminando sua longa vida feliz e famoso, sem ter culpa ou puniçáo.

Mais do que tomar isso como apenas uma indicaçăo da posiçâo ética pessoal do autor, temos um campo mais seguro se pensarmos no público leitor de tal obra. O conto foi escrito em 1892, meros quatro anos após a Aboliçấo. Seus leitores, em número enorme, eram pessoas brancas que, se náo possuíram, elas mesmas, escravos, conheciam e conviviam com outras que possuíram. Se, em 1900, o próprio Joaquim Nabuco, abolicionista, confessava sentir "saudade do escravo" (NABUCO, 1998, p. 183), quâo mais saudosos náo estariam aqueles que foram menos (ou até mesmo nada) contrários à Aboliçăo. Lançada no Rio de Janeiro e tendo três ediçóes durante a vida do autor, Mares e campos foi uma obra bem-sucedida comercialmente, de forma que a enxergar 
como uma obra de entretenimento feita para classes sociais letradas - onde o racismo nâo era incomum - explica a posiçâo ética que dita o tom em um conto como "O velho Sumares".

\subsection{ANÁLISE DE “O NAVIO NEGREIRO”}

Situaçăo diversa encontramos em "O navio negreiro", de Histórias rústicas, uma sátira incisiva contra o tráfico de africanos para o Brasil. Versăo do poema "Das Sklavenschiff", escrito em 1854 pelo poeta alemăo Heinrich Heine, Várzea, tudo indica, adaptou a traduçâo francesa, feita por Gérard de Nerval, que foi bastante difundida no Brasil - por exemplo, Castro Alves baseou-se nessa traduçăo para compor seu poema "O navio negreiro", embora com inúmeras liberdades; há mais diferenças do que semelhanças, até mesmo nas personagens e no tom emocional buscado.

Tanto a versăo francesa de Nerval quanto a de Várzea colocaram em prosa os versos de Heine, sendo bastante fiéis à obra original. Vejamos como cada versâo inicia:

Der Superkargo Mynheer van Koek

Sitzt rechnend in seiner Kajüte;

Er kalkuliert der Ladung Betrag

Und die probabeln Profite. (HEINE, 1854, p. 95).

La capitaine du navire, mynher van Koek, est assis dans sa cabine, occupé à faire ses comptes. Il calcule le prix du chargement et les bénéfices probables. (HEINE, 1874, p. 344).

No camarote, sentado ao beliche, mynher van Koek, o capităo do brigue, póe-se a fazer as suas contas. Calcula o preço de venda do carregamento e os lucros prováveis: [...] (VÁRZEA, 1904, p. 133).

Porém, há razôes para analisarmos a obra e a considerarmos junto daquelas que anteriormente estudamos. Acreditamos ser importante que Várzea quis se apropriar da adaptaçáo como sendo sua, colocando-a entre seus contos originais em nível náo diverso - há apenas o sobrenome "Heine" sutilmente indicado entre o título e o texto, onde em outros contos há dedicatórias, e nenhuma informaçăo sobre a versăo francesa. No mais, além de ser um texto incisivo, denunciador, há breves mas ricas adiçôes feitas pelo contista brasileiro, o que indicaremos em nossa análise.

O conto inicia com van Koek, chefe de embarcaçăo, em seu camarote. Ele está fazendo cálculos em relaçâo a seu carregamento; após considerar a goma, a pimenta, e o marfim e ouro em pó, pensa sobre a carga mais preciosa, a "negra": seiscentos africanos adquiridos em troca de "ninharias" - "aguardente, contas de vidro, facas e canivetes" (VARZEA, 1904, p. 133). Conclui que, chegando com metade do "carregamento", caso sobrevivam “à viagem e às doenças”, terá um bom lucro de 800\% (p. 134).

Adentra o camarote o médico naval, dr. van Smissen. Há uma breve descriçâo: essa personagem possui uma "figura alta e magra, o nariz crivado de rubras verrugas" - distante do ideal de beleza da raça branca que, por exemplo, o capităo Sumares representava. Contente com seus cálculos, van Koek pergunta: "como vâo meus caros negros?" - duplo sentido que nâo está presente no original alemáo ("lieben"; em francês temos "chers"). Van Smissen traz más notícias: a mortalidade entre os africanos 
aumentou de um dia para o outro. Após informar os números e que fez as anotaçōes devidas no livro de óbitos, van Smissen assegura ao capităo que estava certo que os falecidos realmente assim estavam, "porque estes patifes frequentemente fingem de mortos, a fim de serem jogados às vagas. Preferem a morte ao cativeiro..." (VARZEA, 1904, p. 134). Essa última frase năo está presente nem no original alemăo, nem na traduçấo francesa - nelas, é como se os africanos de fato fugissem nadando. Várzea, conhecedor dos mares, sabia que, lançando-se alguém no meio do Oceano Atlântico, năo haveria chance alguma de sobrevivência. Isso imprime, aos homens e mulheres escravizados, coragem e dignidade enormes - além de acentuar o cinismo dos marinheiros.

Seguindo Heine, Várzea, para mostrar a crueldade desses homens, usa de um humor ácido, até mesmo mórbido. Em menos de duas páginas, temos a banalizaçấo da morte, e o desprezo pelo desejo de liberdade de alguns homens e mulheres africanos. O tom se mantém com van Smissen descrevendo os tubaróes que seguem o barco como se fossem seus animais de estimaçāo: seriam seus "pensionários", seguindo o barco graças ao odor dos cadáveres (na opiniâo do médico, eles têm predileçāo por "carne negra"). Também proporcionam momentos "cômicos" ao doutor quando abocanham os mortos - "este arranca a cabeça, aquele a perna, e os outros tassalhos de carne..."; após o banquete, "saracoteiam alegres", olhando nos olhos do médico "como se quisessem agradecer-me o almoço". (VÁRZEA, 1904, p. 134-135).

Van Koek, porém, está preocupado com seus lucros, e pede alguma forma de evitar tantas mortes. Van Smissen sugere uma soluçāo "facílima": "Uns têm morrido por falta de acomodaçôes e pelo mau cheiro do porâo; outros de melancolia. É dar-se-lhes, portanto, um pouco de ar puro no convés, um pouco de música e dança, e o mal desaparecerá". A soluçấo năo é apenas acatada pelo capităo, como este chega a comparar o médico a Aristóteles (que, principalmente em sua obra Política, defende a "escravidăo natural"), o tutor de Alexandre (que escravizava os povos que conquistava); de fato, van Smissen seria até mais sábio que o presidente da "Sociedade de aperfeiçoamento das tulipas". Van Koek informa, entăo, que "ai daqueles a quem a dança năo alegrar!" (VÁRZEA, 1904, p. 135).

A festa é macabra: cerca de cem africanos, nus e acorrentados, dançam sob o estalo dos calabrotes, o que "excita a alegria" (VÁRZEA, 1904, p. 137). Supóe-se que os duzentos ou mais homens e mulheres escravizados restantes estariam fracos demais para subir à popa. Os instrumentos musicais sâo mal tocados por uma banda que soa improvisada: um piloto, o cozinheiro, um grumete e inclusive o próprio médico, que, de acordo com o narrador, toca um pistăo como se fosse um clarim (p. 136), fazendo assim uma relaçấo com o militarismo (algo nâo presente no original ou na traduçấo francesa). Três vezes é repetida as onomatopeias dos sons dos instrumentos - "trátrá-trá" e "dum-dum-dum" - que seriam adequadas também para os golpes de corda dados nos africanos. Os termos săo indicaçăo segura de ser o texto francês, se pelo menos nâo o único, o principal adaptado por Várzea - nele, temos "trara-trara" e "dumdum-dumdum" enquanto que no original alemáo encontramos "Dideldumdei" e "Schnedderedeng".

O narrador informa que os tubarôes, nervosos e famintos, nadam ao redor do navio, mordendo suas caudas, o que prenuncia uma curiosa intervençâo opinativa do próprio narrador. É uma crítica que reforça a veia irônica: “Penso que eles nāo amam a música, 
como alguns de seus iguais". Isso é completado com uma citaçăo de um poeta inglês nâo nomeado: "năo te fies nos animais que nâo amam a música!" (VÁRZEA, 1904, p. 137). A citaçăo é uma síntese de uma passagem mais longa de $O$ mercador de Veneza, de Shakespeare, ato V, cena I. Vale notar que no original e no conto de Várzea a citaçấo está em aspas, o que năo ocorre na versăo francesa - năo sendo mera coincidência, é possível que o autor catarinense tenha tido acesso ao poema em alemáo.

Lembrando da aproximaçăo entre o médico van Smissen e os tubarôes, que seriam mascotes dele, acreditamos que está indicado aqui, com ainda mais força, a relaçáo entre os tubaróes e seus "iguais", os carrascos humanos - ambos algozes dos africanos e inimigos dos ingleses, representados aqui pelo poeta que lembra em quem nâo devemos confiar: os brancos enxergam a música apenas como uma soluçăo técnica para um problema, como se fosse um remédio, e năo uma arte.

Por fim, e reforçando o absurdo, como se fosse a torçăo final da chave irônica, o capităo pede aos céus, em "nome de Jesus" - alguém que, assim como os africanos no barco negreiro, foi preso e torturado - que a vida dos negros, "estúpidos" como bois, seja poupada, para que năo haja prejuízo em seus negócios (VÁRZEA, 1904, p. 138).

Em suas poucas páginas, o conto "O navio negreiro" é de uma crueza que chega às raias do desconforto. A desvalorizaçâo da vida dos africanos é colocada por vários ângulos - para o capităo săo produtos comerciais, o que é feito a eles é comparado com experimentos botânicos, a música é forçada pela violência - de forma que temos uma banalizaçăo da morte e da escravidăo. Năo há, aqui, a despreocupaçăo que encontramos em "O velho Sumares". Havíamos comentado como no conto de Mares e campos nâo há neutralidade - é uma aventura que busca trazer emoçâo ao leitor através das peripécias de um navio negreiro e seu capităo, o herói da história. Mesmo o recorte do conto indica sua tendência. Porém, uma defesa de que o conto está apenas retratando algo verídico, por mais rasa que fosse, seria mais aceitável do que aqui. “O navio negreiro" é tăo excessivo em suas imagens, nos discursos das personagens, que chega a ser brutal.

Devemos indagar por que o mesmo Várzea que exaltou as aventuras de Sumares e ignorou a importância dos negros na formaçăo de Florianópolis decidiu adaptar uma poesia tăo denunciadora como é "Das Sklavenschiff". Vale lembrar que um sarcasmo assim tăo extremo também foi feito visando alguém: uma parte de leitores que se sentiria desconfortável com as descriçōes e que estariam sendo descritos como imorais - antigos escravagistas e seus descendentes, integrantes da sociedade letrada que lia as obras de Várzea; em grande parte, o mesmo público que, nove anos antes, vibrou com as desventuras do Galgo. Ao decidir adaptar Heine ao invés de conceber um conto original, Várzea também se posiciona como parte de um grupo de intelectuais globais que eram contrários aos abusos da escravidâo.

Năo seria exagero concluir que Várzea buscou corrigir sua equivocada posiçăo racial presente em contos e estudos anteriores; mesmo seus dois contos que retratam homens e mulheres negros de forma digna săo ambos de Histórias rústicas, lançado quatro anos após A Ilha. Assim como focou anteriormente nas aventuras dos navios negreiros, como ignorou a presença negra na ilha, passados alguns anos, Várzea foi capaz de admitir a crueldade e injustiça reinantes nessa forma desumana de comércio, além de valorizar mais adequadamente os africanos e afrodescendentes 
que ajudaram a construir a capital de Santa Catarina. As histórias mais recentes de Várzea perderam a visáo enviesada anterior, com a posiçấo do autor passando a ser năo apenas defensiva, mas acusatória.

\section{IDEOLOGIAS E CONCLUSÕES}

Se em A Ilha temos quase um panfleto propagandístico somado a um desejo pela limpeza étnica, e em Mares e Campos uma coletânea de contos focados naquilo que mais representava, para Várzea, o povo de Desterro - marinheiros (sejam pescadores ou traficantes) e lavradores humildes - em Histórias rústicas abre-se um leque maior, em que temos uma presença significativa de afrodescendentes em Florianópolis, e também na Capital Federal, além de uma crítica irônica e severa ao tráfico negreiro. Essa multiplicidade, ao invés de preocupar, deve ser aceita como paradigma da complexidade social pelo qual o Brasil passava na época. As obras que estudamos sâo de 1895, 1900 e 1904: a Aboliçâo estava ainda próxima, com uma quantidade enorme de homens e mulheres negros fora do mercado de trabalho, ou aceitando qualquer serviço, sem que tenha havido qualquer plano de inserçăo dessas pessoas na comunidade dominante. Ao mesmo tempo, temos, em Florianópolis, um grupo de pessoas detentoras de poder com ideias náo tâo novas - a de realizar o branqueamento da populaçáo - do qual faziam parte artistas, estudiosos e políticos, que ignoravam a importância de africanos e afrodescendentes na construçāo e desenvolvimento do estado e de sua capital. E, em Várzea, um autor buscando compreender e retratar essas ambiguidades, com seus próprios conhecimentos, opiniōes e crenças.

Várzea foi um autor envolvido em uma série de ideologias reinantes, as quais às vezes ele aceitou, em outras repeliu. Seja pelas ideias que recebia da sociedade, seja pelo que acreditava precisar escrever para agradar o seu público leitor, toda essa variaçấo é causada por princípios que, mesmo podendo parecer díspares, podem bem conviver. Para fundamentar essas ideias, leiamos como Friedrich Engels articula a noçăo de ideologia. É uma passagem longa, mas que vale pela clareza que proporciona:

Ora, quando algum ideólogo dessa linha formula a moral e o direito a partir do conceito ou dos assim chamados elementos mais simples "da sociedade", em vez de fazê-lo a partir das relaçôes sociais reais das pessoas que o rodeiam, que material ele tem à disposiçâo para realizar essa formulaçâo? Claramente, sâo dois tipos de material: em primeiro lugar, o resíduo escasso do conteúdo real que possivelmente ainda está presente nas abstraçôes colocadas como base e, em segundo lugar, o conteúdo que nosso ideólogo reintroduz a partir de sua própria consciência. E o que ele encontra em sua consciência? Sobretudo, noçóes morais e jurídicas como expressâo - positiva ou negativa, afirmativa ou polêmica - correspondente, em maior ou menor grau, às relaçôes sociais e políticas nas quais ele vive; além disso, talvez encontre concepçôes extraídas da bibliografia pertinente; por fim, possivelmente ache ainda algumas excentricidades pessoais. Nosso ideólogo pode virar e mexer como quiser: a realidade histórica que ele jogou porta afora volta a entrar pela janela e, acreditando esboçar uma teoria moral e jurídica para todos os mundos e todas as épocas, ele de fato confecciona um retrato desfigurado das correntes conservadoras ou revolucionárias do seu tempo - desfigurado por ter 
sido desarraigado do seu chăo real e posto de cabeça para baixo como num espelho côncavo. (ENGELS, 2015, p. 127 (grifos do autor))

Isso se aplica a Várzea: assim como todos os artistas, suas ideias provêm nâo só do talento ou da imaginaçăo, năo só de suas experiências individuais e excentricidades, mas também das "relaçôes sociais e políticas nas quais ele vive". Nâo é estranho, assim, que um escritor que descreve um narrador que lembra de sua infância com saudosismo, focando no amor e admiraçăo que sentia por uma mulher que fugiu do cativeiro da escravidăo, ver o seu presente, em 1900, uma época em que africanos e afrodescendentes estariam reduzindo em número, como sendo algo positivo. Desejo que continuou se cumprindo: com o passar dos anos, a porcentagem de afrodescendentes em Florianópolis que, conforme indicamos, era de 18,26\% em 1890, chegou a ser de 9,28\% em 1940 (CARDOSO \& IANNI, 1960, p. 93) - isto é, o branqueamento foi mais que uma ideia, foi algo aplicado com sucesso por aqueles que detinham o poder, inclusive com ajuda de uma ideologia propagada por pessoas como Várzea, conscientemente ou năo. ${ }^{4}$

Essa ideia, que foi aplicada em Santa Catarina com resultados expressivos, tanto pela segregaçăo de homens e mulheres negros, quanto pelo incentivo à vinda de imigrantes europeus, era algo corrente no Brasil da época. O branqueamento, fruto de interesses sociopolíticos, fundamentava-se mais em desejos do que no embasamento científico, seguindo autores menores e até mesmo já superados algures. Como coloca Lilia Schwarcz (1993, p. 41) a respeito dos estudos realizados no Brasil no final do século XIX, “o que se valorizava nesse momento [...] [era] certa ética científica, uma "cientificidade difusa" e indiscriminada. Tanto que se consumiram mais manuais e livros de divulgaçấo científica do que obras e relatos originais". Sabemos que era esse o caso com Várzea, inclusive. Ao citar as suas influências intelectuais e de seus amigos escritores que trabalhavam na Tribuna Popular, jornal de Desterro, o autor fornece o seguinte e variado grupo, cujos primeiros nomes sâo de pensadores que muito influenciaram os conceitos raciais que eram entăo apregoados no Brasil:

Os nomes célebres e gloriosos de Darwin, Spencer, Haeckel, Kant, Hegel, Schopenhauer, Dickens, Thackeray, Mommsen, Heine, Goethe, Schiller, Taine, Zola, Daudet, Flaubert, Balzac, Maupassant, Richepin, Banville, Baudelaire, Leconte de Lisle, Sully Prudhomme, Coppée, Rollinat, Lombroso, De Amicis, Dante, Leopardi, Gogol, Dostoievski, Turguienoff, Oliveira Martins, Eça, Ramalho, Guerra Junqueiro e Antero de Quental apareciam aí frequentemente, num conjunto constelar. E o livro de cada um desses espíritos eram lidos, devorados sofregamente... (VÁRZEA, 1907, p. 1).

Mesmo que alguns desses autores possam ter produzido obras com eventuais similaridades, temos aqui um verdadeiro "balaio de gatos" intelectual. O que mais chama a atençấo é o encanto do intelectual brasileiro, buscando ler - ou "devorar", em suas próprias palavras - o que lhe caia nas măos, para disso reorganizar ideias até mesmo díspares e criar outras aplicáveis a um país - no caso particular, a uma

4 Para mais mostras de como planos autoritários do século XIX repercutiram ao longo do século XX, sugerimos a segunda parte de Cor e mobilidade social (CARDOSO \& IANNI, 1960), onde Octávio Ianni trata dos esteriótipos raciais presentes na sociedade florianopolitana na década de 1950. 
cidade - com condiçóes deveras diversas daquelas encontradas nos locais onde as obras originais foram criadas.

Concluindo, Virgílio Várzea foi um homem de seu tempo, influenciado por ideias tanto estrangeiras quanto locais, criador de obras com preconceitos raciais, mas inteligente o bastante para notar equívocos e contradiçôes presentes em certas ideias, desenvolvendo assim conclusóes próprias e que mudaram com o passar dos anos. Suas obras ajudam a compreender, também, a sociedade catarinense dominante da época, especificamente, e a brasileira, no geral - onde o autoritarismo, para cumprir sua agenda, infiltrava-se nas artes de maneira tăo natural que mesmo as ideias de um autor náo podem ser compreendidas se năo as buscarmos enxergar como estando afetadas pelo prisma multifacetado de uma ideologia racista. 


\section{REFERÊNCIAS}

CARDOSO, Fernando Henrique \& IANNI, Octávio. Cor e mobilidade social em Florianópolis. Sâo Paulo: Companhia Editora Nacional, 1960.

CESCO, Susana. "Agricultura e Transformaçăo Ambiental: o caso da Ilha de Santa Catarina no século XIX". In: Anais do XXVI Simpósio Nacional de História. Săo Paulo: ANPUH, julho de 2011. Disponível em:

<http://www.snh2011.anpuh.org/resources/anais/14/1300876260_ARQUIVO_Agricult uraetransformacaoambiental-ANPUHok.pdf>. Acesso em 11 jan. 2021.

ENGELS, Friedrich. Anti-Dühring. Sáo Paulo: Boitempo, 2015.

HEINE, Heinrich. Vermischte schriften I. Amsterdam: M. H. Binger \& söhne, 1854.

. Poëmes et légendes. Paris: Michel Lévy Frères, 1874.

KOWARICK, Lúcio. Trabalho e vadiagem. Săo Paulo: Editora 34, 2019.

LIMA, Henrique Espada. "Da escravidâo à liberdade na Ilha de Santa Catarina". In: MAMIGONIAN, B. G. \& VIDAL, J. Z. (orgs). História diversa. Florianópolis: UFSC, 2013, p. 197-223.

MARIA, Maria das Graças. "Clubes e associaçōes de afrodescendentes na Florianópolis das décadas de 1930 e 1940". In: MAMIGONIAN, B. G. \& VIDAL, J. Z. (orgs). História diversa. Florianópolis: UFSC, 2013, p. 263-277.

NABUCO, Joaquim. Minha formaçăo. Brasília: Senado Federal, 1998.

PEDRO, Joana Maria et al. Negro em terra de branco. Porto Alegre: Mercado Aberto, 1988.

SCHWARCZ, Lilia Moritz. 0 espetáculo das raças. Sáo Paulo: Companhia das Letras, 1993.

Nem preto nem branco, muito pelo contrário. Săo Paulo: Claro enigma, 2012.

SOUZA, Luiz Alberto de. "Homens bons para o amanhă: pensamento racial e perspectivas republicanas em A Ilha, de Virgílio Várzea". In: Santa Catarina em História. Florianópolis: UFSC, vol.1, no 1, 2007.

VÁRZEA, Virgílio. Histórias rústicas. Lisboa: Antonio Maria Pereira, 1904.

. “Impressôes da província (1882-1889)". In: Correio da manhă. Rio de Janeiro, 17 de fevereiro de 1907, p. 1-2. Disponível em: <http://hemerotecadigital.bn.br/acervo-digital/correio-manha/089842 (tomo 2045)>. Acesso em 10 fev. 2021.

. Santa Catarina - A Ilha. Florianópolis: Lunardelli, 1985.

Mares e campos. Florianópolis: Insular, 2003.

VERÍSSIMO, José. Estudos da literatura brasileira - quarta série. Rio de Janeiro: Garnier, 1904. 